\title{
Dependence of gas emission from the sources undermined by stope mine workings on the rocks displacement parameters
}

\author{
Mykhailo Filatiev $^{1 *}$, Elvira Filatieva $^{2}$, and Mykola Antoshchenko ${ }^{2}$ \\ ${ }^{1}$ Donbas State Technical University, Mining Department, 84 Peremohy Ave., 93100 Lysychansk, \\ Ukraine \\ ${ }^{2}$ Donbas State Technical University, Department of Ecology, Life Safety and Labor Protection, \\ 84 Peremohy Ave., 93100 Lysychansk, Ukraine
}

\begin{abstract}
The parameters are established in the work of the stope mine workings and rocks displacement, which correspond to the maxima of gas emission into the gas drainage boreholes. The angular and linear parameters of the crustal movement and rocks displacement have been calculated with the use of empirical dependences. These parameters correspond to the maxima of gas emission into the gas drainage boreholes. The obtained positive results for determining the possible areas of maximum gas emission allow us to recommend the empirical dependences for calculating the angles of maximum subsidence and complete displacements at the stage of stope works development, as well as the dimensions of the stope mine workings, at which the processes of rocks displacement reach the earth surface. The established relations between the gas drainage boreholes location and the rocks displacement zones with discontinuity make it possible to design the optimal schemes of drainingout of gases from the gas-and-coal deposits. For the first time, three independent methods have been used to determine the changes in dimensions of rocks displacement zones with discontinuity after the primary main roof squeezing until the formation of stable upper boundaries of these zones.
\end{abstract}

\section{Introduction}

The link between the level of gas emission from coal of the adjacent seams and its residual gas content with the intensity of the undermined rocks displacement is qualitatively confirmed by the results of mine experiments $[1,2]$. The change in gas pressure and absolute methane emission from the undermined seams under the influence of the working stope face has been established by the studies [3]. Up to date, there are no works in which the parameters of rocks displacement and gas emission would have been considered together when removing the stope faces from the first cut workings in the initial period of the extraction sites operation.

Consideration of this issue is relevant to the creation of safe conditions during the stope works performance, as in this period the primary and subsequent squeezing of the main roof

\footnotetext{
*Corresponding author: mfilatev@gmail.com
} 
occurs and the gas emission maximum is reached from the undermined coal and rock stratum. It has been established [4], that when removing a stope face from the face entry after the squeezing of the main roof, a periodic increase in methane emission into the gas drainage boreholes and into mine workings, is observed. Methane emission $\left(I_{m}^{0}\right)$ into gas drainage boreholes begins since removal of the stope face from the first cut working $\left(L_{m}^{0}\right)$ at a certain distance. And then there is an increase in gas emission and achieving of its maximum. After the first maximum $\left(I_{m}^{1}\right)$, a decrease in methane emission is observed, and then there is an increase and the achievement of the next maximum of gas emission occurs. The alternation of gas emission maxima is determined through the entire time of mining the working area [5]. This is obviously caused by the periodic roof rocks squeezing as the stope face is removed from the face entry. On the basis of mine observations, it is possible to determine reliably the distances between the stope face and the first cut working $(L)$, at which the gas emission maxima occur. According to the empirical dependences [6-10], it is possible to calculate the values of the angles of maximum subsidence of the earth surface $(\theta)$ and the complete displacement of the undermined rocks $\left(\psi_{1}, \psi_{2}, \psi_{3}\right)$ with high accuracy (correlation ratios $(R)$ more than 0.90$)$ in relation of $L$ to the depth $(H)$ of stope works performance.

The maximum subsidence angle $(\theta)$ - from the side of the seam gradient, formed on the vertical section in the main cross section of the trough, transverse the course of seam by the horizontal line and the line connecting the middle of the mine working with the point of maximum subsidence at incomplete undermining of the earth surface [9]. According to the results of surveying observations [6], the empirical dependence has been obtained:

$$
\theta=86.3-56.5 \exp \left[4\left(\frac{L}{H}\right)^{-1.9}\right], \text { degree. }
$$

According to the normative document [11], the angles of complete displacements are internal relative to the mined-out space formed on the vertical sections along the main cross sections of the trough. The flat bottom of the shift trough of the earth surface in the initial period of the extraction area operation is not formed. For this reason, the angles of complete displacements $\left(\psi_{1}, \psi_{2}, \psi_{3}\right)$ are suggested to be calculated for flat seams according to the dependence [6]:

$$
\psi=93.7 \cdot \exp \left(-0.42 \cdot \frac{L}{H}\right), \text { hail. }
$$

In this case, the determination of the angles $\left(\psi_{1}, \psi_{2}, \psi_{3}\right)$ was made by connection of the experimental point of maximum subsidence of the earth surface by means of one line segment with the fixed wall of the face entry, and by the second line segment - with the stope face position corresponding to this point.

The equation (2), with a high degree of probability, describes the change in the complete displacement angles at values of $L / H \leq 1$ as from the side of the first cut working $\left(\psi_{3}\right)$ so from the side of the stope face $\left(\psi_{p}\right)$. At $L / H>1$, the angles of complete displacements from the side of the stope face were in the range of $50-60^{\circ}$ and averaged $55^{\circ}$ [6]. Such values coincide with the recommendations of the normative document [10].

In addition to the angular parameters of the rocks displacement and the crustal movement, some characteristic linear dimensions of the stope mine workings are important. These include $L_{H}$ and $L_{m} . L_{H}$ is the removal of the stope face from the first cut working, at which the processes of rocks displacement reach the earth surface. According to [11], $L_{H}=(0.1 \div 0.3) \cdot H$. The parameter $L_{H}$ depends on the seam thickness $(\mathrm{m})$, the depth $(H)$ of 
the stope works performance and the rate of the stope face advance $\left(v_{e x t r}\right)$. It is uniquely determined by the equation [6]:

$$
L_{H}=H \cdot[(0.329-0.096 \cdot m) / 0.223] \cdot\left(0.002 \cdot v_{e x t r}+0.145\right), \mathrm{m} .
$$

The final formation of complete displacement area of the roof rocks occurs when the stope face is removed from the first cut working at a distance L, which is equal to the length of the longwall face or to the width of the mined-out space formed during the mining of several adjacent longwall faces $L_{l}$. In the mining extracted area of the longwall, a square is formed of the mined-out space, which is the zone of stope works influence. At further advance of the longwall, the zone of the mined-out space influence is formed, in which the parameter $H_{p}$ of complete roof displacement is not changed until the longwall mining of the entire mining extracted area [12]. Based on this scientific position, the limit value of the height of the rocks displacement zone with discontinuity $\left(H_{p}\right)$ is formed, when removing the stope face from the first cut working at a distance $L \geq L$.

Thus, the purpose of the work is to determine the parameters of the stope mine workings and the rocks displacements corresponding to the maxima of gas emission into the gas drainage boreholes. To do this, on the basis of mine experiments, it is necessary to determine the maxima of methane emission into the gas drainage boreholes drilled above the installation chambers, and corresponding removals of stope faces from the first cut workings. Having determined the dimensions of the stope mine workings and using empirical dependences, it is possible to calculate the angular and linear parameters of the crustal movement and rocks displacements corresponding to the maxima of gas emission into the gas drainage boreholes.

\section{The research results}

The studies were performed for the conditions of the anthratscite seam $l_{2}^{\beta}$ mining by Gazeta Izviestiia Mine, SE Donbasantratsyt (Ukraine). The thickness of the mined seam was $0.9 \mathrm{~m}$; the incidence angle was $2-3^{\circ}$. The longwalls ( 2 nd bis and 3rd Western) were mined out by heading-and-stall method, their lengths were 185 and $205 \mathrm{~m}$, (Fig. 1). The average rate of the stope face advance of the 2 nd bis Western longwall for the entire observation period was $0.7 \mathrm{~m} /$ day, and of the $3 \mathrm{rd}$ Western longwall $-2.8 \mathrm{~m} /$ day. The depth of the stope works performance is $290 \mathrm{~m}$.

In addition to the distances between the stope faces and the first cut workings, at which the maxima of gas emission were observed (Fig. 2), the distances corresponding to the beginning of the crustal movement $\left(L_{H}\right)$ and the formation of the square of mined-out space ( $L=L_{l}$ ), have been also taken into consideration during analysis.

For each characteristic dimension of the stope mine working (removal of the stope face) according to the equations $(1,2)$, the angles $\theta$ and $\psi_{p}$ (Table 1) have been calculated, respectively. The parameter $L_{H}$ is determined using equation (3). It shows that with such a dimension of the stope face, the displacement processes of the undermined rocks reach the earth surface, and the disturbance of the original natural state occurs in the entire coalbearing strata. Upon availability of intersecting fractures, this creates conditions for the desorption of gas from the undermined seams and enclosing rocks. 


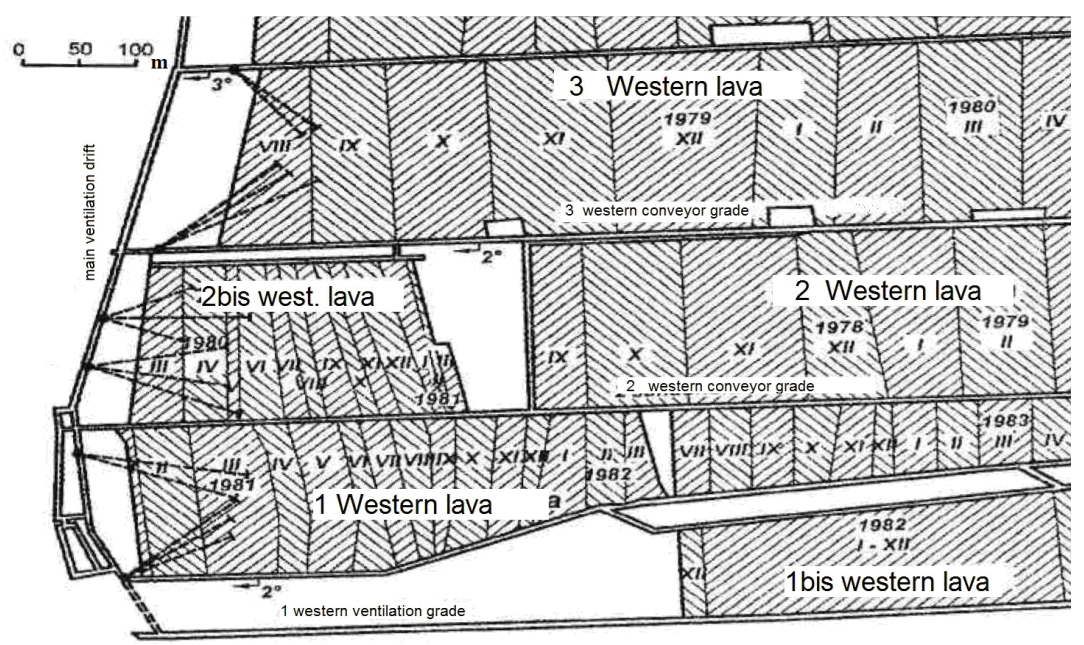

Fig. 1. A fragment of the plan for mining works through a stratum of Gazeta Izviestiia Mine, SE "Donbasantratsyt".

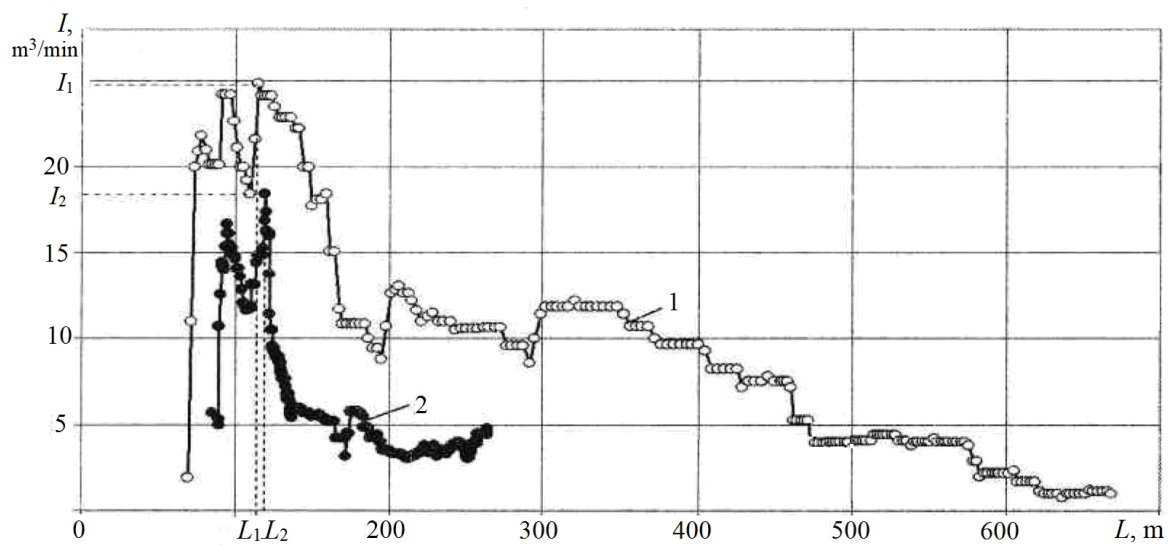

Fig. 2. Dependence of the flow rate $I$ into the boreholes on distance $L$ between the first cut workings and stope faces; 1 and 2 - change in gas emission into the boreholes of the 3-rd and 2-nd bis of the Western longwalls; $\circ, \bullet-$ experimental data.

The rocks displacement zone with discontinuity corresponds to these conditions. Its upper boundary $H_{p}$ is determined in three ways using different initial parameters of rocks displacement. The values $H_{p}^{\prime}$ and $H_{p}^{\prime \prime}$ (Table 1) are determined according to [6]:

$$
\begin{gathered}
H_{p}^{\prime}=L \cdot \frac{\operatorname{tg} \psi}{2}, \mathrm{~m} ; \\
H_{p}^{\prime \prime}=H \cdot \frac{\operatorname{tg} \psi}{\operatorname{tg} \psi_{p}}, \mathrm{~m},
\end{gathered}
$$

where $L$ is a removal of the stope face from the first cut working, $\mathrm{m} ; \psi=55^{\circ}$ are the average values of complete displacement angles with sufficient stope works development 
(at $L / H>1$ ); $H$ is the depth of work performance, $\mathrm{m} ; \psi_{p}$ is the angle corresponding to the maximum subsidence of the earth surface from the side of the first cut working when removing the stope face at a distance $L$.

To determine the parameter $H_{p}^{\prime \prime \prime}$, a graphical method has been used. According to this method, the upper boundary of the rocks displacement zone with discontinuity has been determined by the point of line segment intersection, which determines the maximum subsidence of the earth surface, with a segment corresponding to the average value of the angle $\psi$. This method is designed to confirm the idea of compliance of the maximum gas emission with maximum rocks displacement.

Table 1. The initial experimental data on gas emission into the gas drainage boreholes and the calculated parameters of displacement of coal and rock stratum.

\begin{tabular}{|c|c|c|c|c|c|c|c|}
\hline \multirow{2}{*}{$\begin{array}{l}\text { Characteristic indicators of gas } \\
\text { emission and crustal movement }\end{array}$} & \multirow{2}{*}{$\begin{array}{l}\text { The distance } \\
\text { between the } \\
\text { stope face and } \\
\text { the first cut } \\
\text { working } L, \mathrm{~m}\end{array}$} & \multirow{2}{*}{$L / H$} & \multicolumn{5}{|c|}{$\begin{array}{l}\text { Parameters of the undermined rocks } \\
\text { displacement }\end{array}$} \\
\hline & & & $\begin{array}{c}\theta, \\
\text { degree }\end{array}$ & $\begin{array}{c}\psi_{p}, \\
\text { degree }\end{array}$ & $\begin{array}{c}H_{p}^{\prime}, \\
\mathrm{m}\end{array}$ & $\begin{array}{c}H_{p}^{\prime \prime} \\
\mathrm{m}\end{array}$ & $\begin{array}{r}H_{p}^{\prime \prime \prime} \\
\mathrm{m}\end{array}$ \\
\hline \multicolumn{8}{|c|}{ 2nd bis Western longwall } \\
\hline $\begin{array}{l}\text { Beginning of the crustal } \\
\text { movement }\end{array}$ & 59 & 0.20 & 86 & 86 & 42 & 29 & 40 \\
\hline Beginning of gas emission $I_{m}^{0}$ & 83 & 0.29 & 86 & 83 & 59 & 51 & 58 \\
\hline $\begin{array}{l}\text { The first maximum of gas } \\
\text { emission } I_{m}^{1}\end{array}$ & 89 & 0.31 & 86 & 82 & 64 & 58 & 62 \\
\hline $\begin{array}{l}\text { The second maximum of gas } \\
\text { emission } I_{m}^{2}\end{array}$ & 127 & 0.43 & 86 & 78 & 90 & 88 & 90 \\
\hline $\begin{array}{l}\text { The third maximum of gas } \\
\text { emission } I_{m}^{3}\end{array}$ & 160 & 0.55 & 86 & 74 & 114 & 118 & 116 \\
\hline $\begin{array}{l}\text { Removal of the stope face at a } \\
\text { distance } L_{l}\end{array}$ & 185 & 0.64 & 86 & 72 & 132 & 134 & 130 \\
\hline \multicolumn{8}{|c|}{ 3rd Western longwall } \\
\hline $\begin{array}{l}\text { Beginning of the crustal } \\
\text { movement }\end{array}$ & 99 & 0.34 & 86 & 81 & 70 & 65 & 70 \\
\hline Beginning of gas emission $I_{m}^{0}$ & 75 & 0.26 & 86 & 84 & 53 & 43 & 48 \\
\hline $\begin{array}{l}\text { The first maximum of gas } \\
\text { emission } I_{m}^{1}\end{array}$ & 80 & 0.28 & 86 & 83 & 57 & 51 & 52 \\
\hline $\begin{array}{l}\text { The second maximum of gas } \\
\text { emission } I_{m}^{2}\end{array}$ & 104 & 0.36 & 86 & 81 & 74 & 65 & 68 \\
\hline $\begin{array}{l}\text { The third maximum of gas } \\
\text { emission } I_{m}^{3}\end{array}$ & 114 & 0.39 & 86 & 80 & 81 & 73 & 80 \\
\hline $\begin{array}{l}\text { The fourth maximum of gas } \\
\text { emission } I_{m}^{4}\end{array}$ & 202 & 0.70 & 86 & 70 & 143 & 150 & 136 \\
\hline $\begin{array}{l}\text { Removal of the stope face at a } \\
\text { distance } L_{l}\end{array}$ & 205 & 0.71 & 86 & 70 & 146 & 150 & 140 \\
\hline
\end{tabular}

As an example, a graphical interpretation is given of the change in the displacement parameters of the undermined coal and rock stratum, as well as the earth surface (Fig. 3). 
The close values of the calculated parameters $\left(H_{p}^{\prime}, H_{p}^{\prime \prime}\right.$ and $\left.H_{p}^{\prime \prime \prime}\right)$ for different distances between the stope face and the first cut working (Table 1) indicate approximately the same reliability of the results obtained by different methods. This is also an indirect confirmation of the compliance of the gas emission maxima with maximum rocks displacement.

The beginning of gas emission into the boreholes and its achievement of the first maximum value is caused by the primary main roof squeezing. In the cases under consideration (see Table 1), the beginning of the crustal movement and the achievement of the first gas emission maximum occurred approximately with the same removal of stope faces from the first cut workings. This is due to the low depth of the stope works ( $H=290 \mathrm{~m}$ ). It should be expected that, when performing the stope works at deeper horizons, the beginning of gas emission into gas drainage boreholes will occur much earlier than the beginning of the crustal movement.

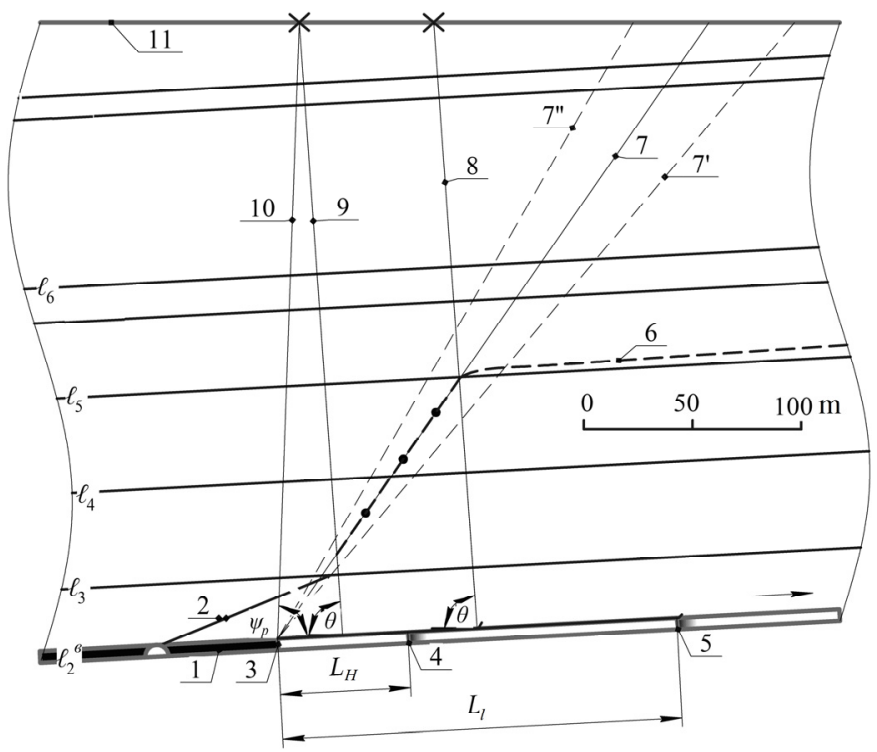

Fig. 3. The scheme of parameters relation of gas emission and rocks displacement in the operation of the 2-nd bis of the Western longwall: 1 - the mined seam; 2 - gas drainage boreholes; 3 - first cut working; 4, 5 - removals of the stope face from the first cut working, respectively, when the rocks displacement processes reach the earth surface $L_{H}$ and formation of the square of the mined-out space with the side, which is equal to the length of the longwall $\left(L_{l}\right) ; 6$ - the upper boundary of the rocks displacement zones with discontinuity; 7 - the line segment, which determines the average angle $\psi=55^{\circ} ; 7^{\prime}, 7^{\prime \prime}-$ the line segments, corresponding to the values $\psi=50^{\circ}$ and $60^{\circ} ; 8,9$ - the line segments, which determine the angles of maximum subsidence of the earth surface $(\theta)$, respectively, at $L=L_{l}$ and $L=L_{H} ; 10$ - angle $\psi_{p}$, corresponding to $L_{H} ; 11$ - the earth surface; $\times$ - the points of maximum rocks subsidence at $L=L_{H}$ and $L=L_{l} ; \bullet-$ the points of maximum rocks subsidence, which correspond to the removals of the stope face from the first cut working, when reaching the maxima of gas emission; $\longrightarrow$ - the direction of the stope face advance.

The first maxima of methane emission in the cases under consideration occurred after the beginning of gas emission with the further advance of stope faces at $5 \div 6 \mathrm{~m}$. All the following maxima of gas emission were recorded when removing the stope faces from the 
face entries at distances less than the length of the longwall (see Fig. 3, Table 1), which corresponds to the scientific position [12]. When removing the stope faces from the face entries at distances more than $L_{l}$, a decrease in gas emission into the boreholes has been observed (see Fig. 2). This indicates the absence of additional methane inflow from the overlying coal and rock stratum and confirms the parameter $H_{p}$ constancy in the subsequent stope face advance.

At $L>L_{l}$, the maximum rocks displacement, and, consequently, the maximum gas emission depend only on the position of the stope face relative to the undermined rocks. The efficiency of draining-out of gases, all other things being equal, will be determined by the location of the working sections of the boreholes in the undermined coal and rock stratum relative to the stope face.

The values close to each other $H_{p}^{\prime}, H_{p}^{\prime \prime}$ and $H_{p}^{\prime \prime \prime}$ (see Table 1), obtained by different methods, indicate that the changes in the angles of maximum subsidence $(\theta)$ and complete displacements $(\psi)$ in the stope works development can be accurately determined using the parameter $L / H$.

\section{Conclusions}

The maxima of methane emission into the boreholes drilled above the first cut workings are observed in the interval after the primary main roof squeezing till the removal of stope faces from the installation chambers at a distance not less than the length of the longwall.

With the development of the stope works, the position of the gas emission maxima is determined by the dimensions of the stope mine workings and the angle of maximum rocks subsidence.

For the first time, three independent methods have been used (including on the dynamics of gas emission) to determine changes in dimensions of rocks displacement zones with discontinuity after the primary main roof squeezing until the stable upper boundaries formation of these zones.

Into the gas drainage boreholes, the faces of which were located at a distance of $30 \mathrm{~m}$ from the mined seam, methane came from the complete displacement zones, the upper boundary of which was located at a distance of $130 \div 140 \mathrm{~m}$.

The close results of the upper boundaries determinination of the rocks displacement zones with discontinuity by means of three independent methods, indicate about the reliability of the initial empirical data used in the calculations.

The established relations between the gas drainage boreholes location and the rocks displacement zones with discontinuity (see Fig. 3) make it possible to design the optimal schemes of draining-out of gases from the gas-and-coal deposits.

The obtained positive results for determining the possible areas of maximum gas emission allow us to recommend the empirical dependences for calculating the maximum subsidence angles and complete displacements at the stage of stope works development, as well as the dimensions of the stope mine workings, at which the processes of rocks displacement reach the earth surface

The authors express their gratitude to the management of the Gazeta Izviestiia Mine, SE "Donbasantratsyt" for providing the experimental data for the research work.

\section{References}

1. Morev, A.M., \& Yevseyev, I.M. (1975). Degazatsiya sblizhennykh plastov. Moskva: Nedra. 
2. Bondarenko, V.I., Kharin, Ye.N., Antoshchenko, N.I., \& Gasyuk, R.L. (2013). Basic scientific positions of forecast of the dynamics of methane release when mining the gas bearing coal seams. Naukovyi Visnyk Natsionalnoho Hirnychoho Universytetu, (5), 24-30.

3. Ayruni, A.T. (1981). Teoriya i praktika bor'by s rudnichnymi gazami na bol'shikh glubinakh. Moskva: Nedra.

4. Antoshchenko, N.I., Okalelov, V.N., \& Pavlov, V.I. (2013). Formirovanie dinamiki metanovydeleniya iz podrabatyvayemogo massiva pri otrabotke gazonosnykh ugol'nykh plastov. Alchevsk: Donbaskyi derzhavnyi tekhnichnyi universitet.

5. Antoshchenko, N.I., Koptikov, V.P., \& Filimonov, P.Ye. (2014). Bezopasnaya otrabotka gazonosnykh ugol'nykh plastov s uchetom geomekhanicheskikh protsessov sdvizheniya podrabotannykh porod. Alchevsk: Donbaskyi derzhavnyi tekhnichnyi universitet.

6. Dubovik, A.I., Filat'ev M.V., \& Filat'eva, E.N. (2017). Inzhenernaya geomekhanika pri otrabotke ugol'nykh plastov. Lysychansk: Donbaskyi derzhavnyi tekhnichnyi universitet.

7. Filat'ev, M.V., Antoshchenko, N.I., Gasyuk, R.L., \& Pyzhov, S.V. (2015). Eksperimental'noye opredeleniye uglov maksimal'nykh osedaniy podrabotannykh ochistnymi vyrabotkami porod. Ugol' Ukrainy, (11), 3-6.

8. Filat'ev, M.V., Antoshchenko, N.I., Pyzhov, S.V., \& Dubovik, A.I. (2016). Opredelenie zon sdvizheniya podrabotannykh porod s razryvom sploshnosti. Ugol' Ukrainy, (3), 9-16.

9. Filatiev, M. (2017). Determination of cross-correlation dependences between the parameters of swallies of the earth surface and the movement of underworked rocks. Naukovyi Visnyk Natsionalnoho Hirnychoho Universytetu, (3), 43-48.

10. Filatiev, M. (2017). Analytical determination of co-ordinates of d istinguished points of the Earth surface depression over broken workings. Naukovyi Visnyk Natsionalnoho Hirnychoho Universytetu, (1), 27-33.

11. GSTU 101.00159226.001-2003. (2004). Pravyla pidrobky budivel, sporoud i pryrodnykh obiektiv pry vydobuvanni vuhillia pidzemnym sposobom. Kyiv: Ministersto palyva ta enerhetyky Ukrainy.

12. Lobkov, M.I. (2012). Rozvytok naukovykh osnov prohnozu obvalennia porid pokrivli pry vyimanni lavoiu polohoho plasta. Ph.D. Instytut fizyky hirnychykh protsesiv. 